\title{
Studi Numerik Penambahan Pelat Pengaku Diagonal Pada Steel Plate Shear Wall (SPSW) dengan Adanya Variasi Opening
}

\author{
Novin Agustina Nur Putri ${ }^{1, *}$, Budi Suswanto ${ }^{1}$ \\ Departemen Teknik Sipil, Institut Teknologi Sepuluh Nopember, Surabaya ${ }^{1}$
} Koresponden*,Email: novinagustina15@gmail.com

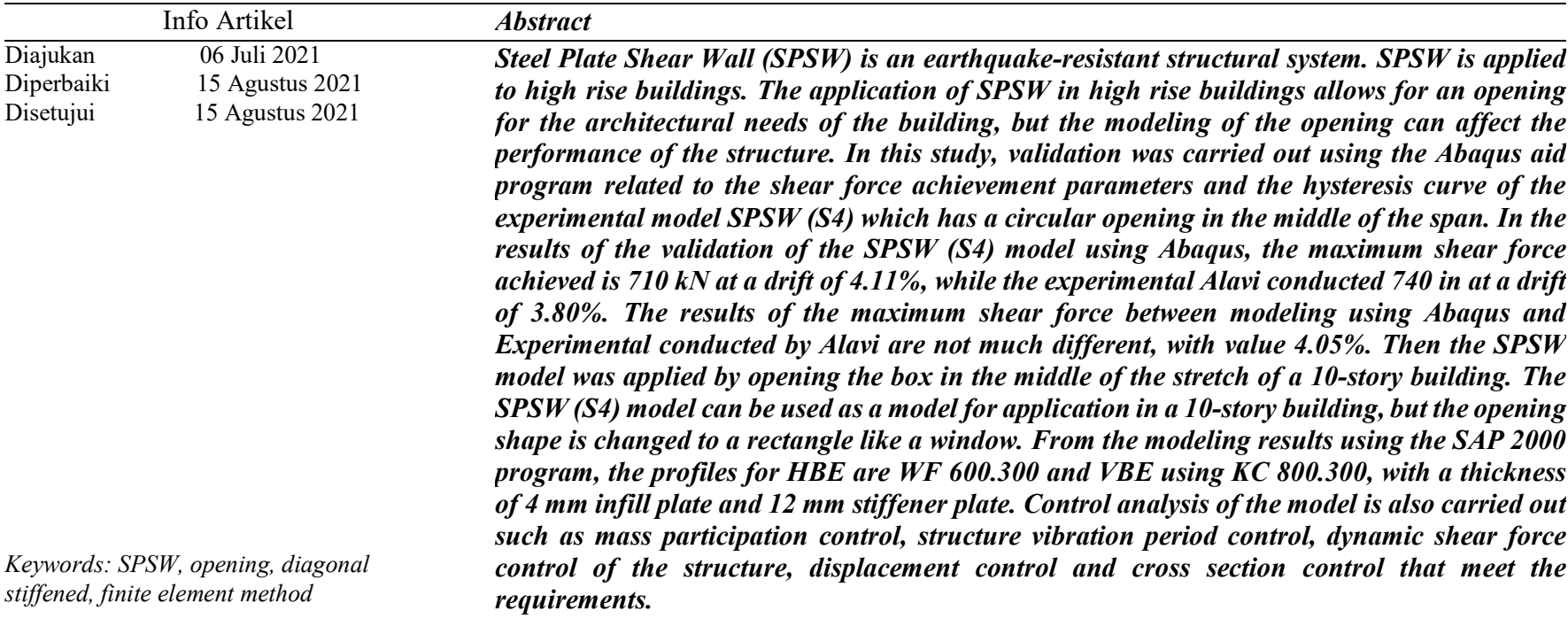

\begin{abstract}
Abstrak
Steel Plate Shear Wall (SPSW) merupakan sistem struktur penahan gempa yang diterapkan pada gedung tinggi. Penerapan SPSW pada gedung tinggi memungkinkan adanya opening untuk kebutuhan arsitektural gedung, akan tetapi pemodelan opening dapat mempengaruhi kinerja struktur. Pada penelitian ini, dilakukan validasi menggunakan program bantu Abaqus terkait parameter capaian gaya geser dan kurva histeresis model eksperimental SPSW(S4) yang memiliki opening berbentuk lingkaran pada tengah bentang. Pada hasil validasi model SPSW(S4) menggunakan Abaqus, capaian gaya geser maksimal yang dihasilkan yaitu $710 \mathrm{kN}$ pada saat drift $4,11 \%$, sedangkan pada eksperimental yang dilakukan Alavi $740 \mathrm{kN}$ pada drift 3,80\%. Hasil capaian gaya geser antara pemodelan menggunakan Abaqus dan Eksperimental yang dilakukan Alavi tidak jauh berbeda yaitu $4.05 \%$. Kemudian dilakukan pengaplikasian model SPSW dengan opening kotak pada tengah bentang untuk Gedung 10 lantai. Sehingga model SPSW(S4) dapat dijadikan model untuk pengaplikasian pada gedung 10 lantai, akan tetapi bentuk opening diubah menjadi persegi panjang seperti jendela. Dari hasil pemodelan menggunakan program bantu SAP 2000 didapatkan profil untuk HBE yaitu WF 600.300 dan VBE menggunakan KC 800.300, dengan ketebalan pelat pengisi $4 \mathrm{~mm}$ dan pelat pengaku $12 \mathrm{~mm}$. Pengontrolan analisis pada model juga dilakukan seperti kontrol partisipasi massa, kontrol periode getar struktur, kontrol gaya geser dinamis struktur, kontrol simpangan dan kontrol penampang yang telah memenuhi persyaratan.
\end{abstract}

Kata kunci: SPSW, opening, pelat pengaku diagonal, metode elemen hingga
SPSW dijelaskan pada AISC Seismic design guidlines dan FEMA P-750. SPSW diharapkan dapat memberikan kapasitas deformasi inelastis yang signifikan, melalui pembentukan plastic-hinge di ujung HBE. VBE diharapkan tidak terjadi leleh akibat geser dan lentur kecuali pada dasar kolom [2].

Pada dasarnya terdapat dua macam tipe pelat pengisi SPSW, yaitu SPSW tanpa pengaku (unstiffened) dan dengan pengaku (stiffened). SPSW dengan pengaku dapat mencegah 
terjadinya tekuk pada pelat pengisi dan SPSW dapat mengalami leleh maksimum sebelum tekuk terjadi, sehingga disipasi energi dapat diserap maksimal oleh struktur [3]. Sedangkan SPSW tanpa pengaku lebih cenderung mengalami pascatekuk akibat dari tegangan geser saat dilakukan pembebanan lateral secara maksimal [4]. Pada kondisi pasca tekuk, pelat pengisi yang tidak menggunakan pengaku, gaya tarik pada pelat pengisi setelah tekuk elastis ditransfer keluar dari bidang pelat ke sambungan HBE dan VBE. Serta penggunaan pelat tipis dan ramping mengakibatkan tingkat kapasitas tegangan geser yang sangat rendah di pelat. Sehingga efek pinching yang signifikan seringkali muncul dalam kurva histeretik, khususnya ketika sambungan balok ke kolom tidak daktail [5].

Salah satu keuntungan penggunaan SPSW untuk gedung tinggi yaitu memungkinkan adanya opening untuk kebutuhan arsitektural gedung dan pengerjaan konstruksinya lebih cepat, bila dibandingkan dengan dinding geser dari beton. Pada sistem struktur SPSW yang memiliki kebutuhan akan opening seringkali mempengaruhi kinerja sistem struktur, sehingga perencanaan bentuk dan dimensi opening harus diperhatikan. Penelitian eksperimental terkini yang dilakukan Alavi, dkk. [6] meninjau adanya opening berbentuk lingkaran dengan diameter $400 \mathrm{~mm}$ atau $1 / 3$ dari tinggi satu modul VBE dan menambahkan diagonal stiffened pada pelat pengisi, hasil penelitian dari pembebanan siklik, efek pinching pada spesimen tidak terjadi, akan tetapi nilai rasio daktilitas struktur SPSW dengan opening lebih rendah ( $\mu=$ $8,7)$ dari SPSW dengan diagonal stiffened tanpa opening ( $\mu$ $=9,3$ )

Penelitian eksperimental lanjutan terkait SPSW yang terdapat opening juga dilakukan Sabouri et al [7]meninjau opening jendela dengan ukuran $258 \mathrm{~mm}$ X $488 \mathrm{~mm}$ dan menambahkan cross stiffened pada pelat pengisi. Dari penelitian ini dapat ditarik kesimpulan, bahwa pada spesimen dengan lebar efektif opening mencapai $63 \%$ dapat mengurangi kekakuan dan gaya geser ultimate sebesar $22 \%$ dan $36 \%$ dari spesimen SPSW tanpa opening. Akan tetapi pada sambungan horizontal dan vertikal yang mengelilingi opening mengalami cracked dan reptured dikarenakan kekakuan yang lebih tinggi dari pada pelat pengisi.

Penelitian eksperimental lainnya yang berfokus pada tipe pelat pengaku SPWS dilakukan oleh Hadad dkk. [8], dengan 3 tipe pelat pengaku yaitu cross-stiffened (CS-SPSW), circular-stiffened (CRS-SPSW), dan diagonal stiffened (DSSPSW). Dari hasil eksperimental dapat ditarik kesimpulan, bahwa kekakuan tertinggi diperoleh oleh CS-SPSW, tetapi penurunan kekakuannya tidak menguntungkan, ditandai dengan ada beberapa cross-stiffened tidak bisa mencapai pelelehan pertama. Selain itu, karena penyusutan kekakuan, stabilitas struktur perlu dievaluasi. Struktur dengan degradasi kekakuan bertahap, mampu mendistribusikan kembali deformasi plastis dan memberikan deformasi inelastik yang lebih besar. Dari aspek ini, kekakuan DS-SPSW menunjukkan degradasi yang lebih baik, mengindikasikan bahwa panel dengan pengaku diagonal berkinerja lebih baik.

Penelitian SPSW ini fokus pada SPSW dengan adanya variasi opening dan penerapan pelat pengaku diagonal pada pelat pengisi. Metode yang akan digunakan yaitu finite element method (FEM) dengan program bantu Abaqus untuk validasi model, serta dilakukan pengaplikasian SPSW dengan adanya opening dan pelat pengaku pada perencanaan Gedung 10 Lantai dengan program bantu SAP 2000.

\section{Metode}

Pada penelitian ini dilakukan dua metode analisis yaitu dengan menggunakan metode elemen batas (finite element method) dengan program bantu Abaqus dan metode analisis respon spektrum untuk Gedung 10 lantai menggunakan program bantu SAP 2000. Analisis elemen batas digunakan untuk validasi model SPSW(S4) [6], sedangkan analisis full load menggunakan program bantu SAP 2000 digunakan untuk pengecekan model SPSW dengan opening ketika diterapkan pada gedung tinggi.

\section{A. Validasi menggunakan Program Bantu Abaqus}

Validasi model dilakukan pada spesimen SPSW(s4) dari penelitian Alavi [6]. Spesimen SPSW(s4) merupakan spesimen SPSW yang memili opening lingkaran pada tengah bentang, serta memiliki penngaku diagonal pada pelat pengisi. Metode elemen batas dilakukan dengan memodelkan elemen SPSW(s4) dengan rasio lebar-tinggi 1,33. Rasio lebar-tinggi ini mempresentasikan perbandingan antara lebar HBE $2 \mathrm{~m}$ dengan tinggi VBE $1.5 \mathrm{~m}$.

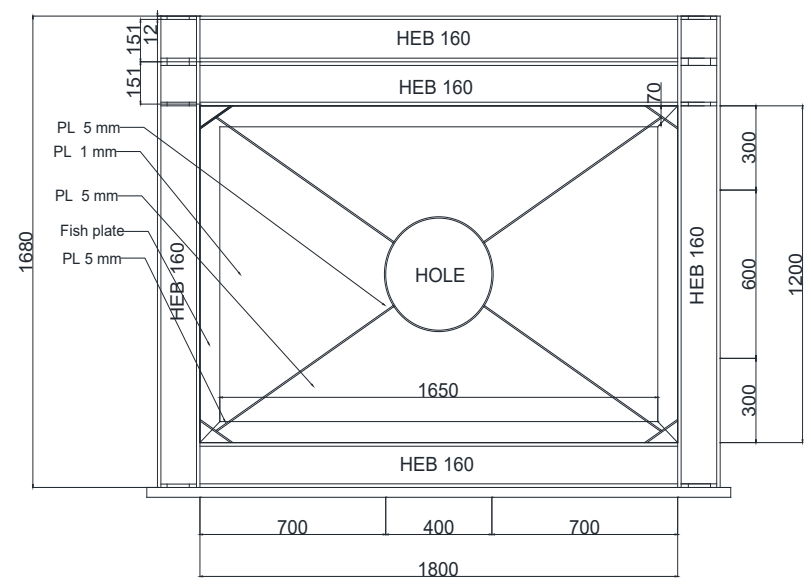

Gambar 1. Model SPSW(S4) [6] 
Pada Gambar 1, profil untuk HBE dan VBE menggunakan HEB 160, sedangkan pelat pengisi SPSW menggunakan pelat baja dengan ketebalan $1 \mathrm{~mm}$ dan pelat pengaku menggunakan tebal pelat $5 \mathrm{~mm}$. Elemen VBE dan HBE menggunakan material dengan tegangan leleh $\left(f_{y}\right)=340 \mathrm{MPa}$ dan tegangan tarik $\left(f_{u}\right)=450 \mathrm{MPa}$, untuk pelat pengisi nilai $f_{y}=280$ MPa $\operatorname{dan} f_{u}=500 \mathrm{MPa}$, sedangkan pelat pengaku yang dipasang pada pelat pengisi nilai $f_{y}=340 \mathrm{MPa} \operatorname{dan} f_{u}=470 \mathrm{MPa}$, dengan Gambar 2 untuk grafik stress-strain pada HBE dan VBE.

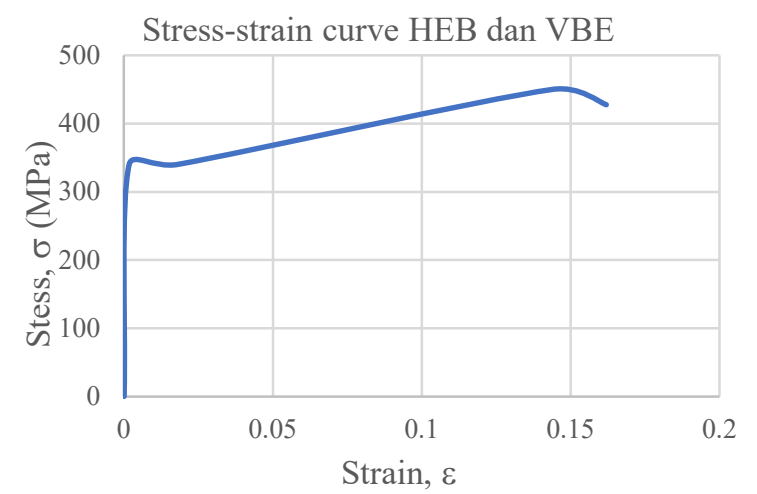

Gambar 2. Grafik Stess-Strain HEB dan VBE

Spesimen dimodelkan dengan tipe elemen C3D8R yang artinya spesimen dimodelkan secara tiga dimensi dengan bentuk solid continum element yang memiliki 8 nodal dimana setiap nodal memiliki tiga derajat kebebasan. $\mathrm{R}$ pada tipe elemen merupakan reduce integration elements bertujuan mengurangi integrasi elemen tanpa mengurangi hasil akurasinya [9], [10]. Sambungan antar elemen menggunakan surfacedbased tie constraints yang pada setiap nodal permukaan pertama (slave surface) akan memiliki nilai sama untuk derajat kebebasannya dengan nodal pada permukaan kedua (master surface). Tipe tie constraints digunakan untuk menyatukan part yang menggunakan sambungan las [10].

Pembebanan pada spesimen dilakukan dengan metode displacement control menggunakan beban siklik yang mengacu protokol ATC-24 untuk pembebanan siklik, dengan pembebanan ke arah $\mathrm{u}_{3}$. Beban siklik diinput pada boundary condition dengan step dan displacement seperti pada Gambar 3.

\section{B. Pengaplikasian SPSW dengan Opening menggunakan Program Bantu SAP 2000}

Pada awal pemodelan digunakan metode analisis menggunakan respons spektrum dengan pemodelan Gedung 10 lantai pada program bantu SAP 2000. Material yang digunakan untuk HBE dan VBE yaitu A572 Gr 50 dan untuk material pelat pengisinya yaitu A203 Gr B, dengan lebar bangunan $28 \mathrm{~m}$, panjang bangunan $20 \mathrm{~m}$, tebal pelat pengisi
$4 \mathrm{~mm}$, pelat pengaku $12 \mathrm{~mm}$, lebar SPSW $5 \mathrm{~m}$ dan tinggi SPSW $4 \mathrm{~m}$. Tabel 1 merupakan profil yang digunakan pada analisis.

Tabel 1. Profil yang digunakan pada SAP 2000

\begin{tabular}{cccc}
\hline Lantai & Kolom & $\begin{array}{c}\text { Balok Arah } \\
\text { Vertikal }\end{array}$ & $\begin{array}{c}\text { Balok Arah } \\
\text { Horizontal }\end{array}$ \\
\hline $1-4$ & KC & WF & WF \\
& $800 \times 300 \times 13 \times 24$ & $600 \times 300 \times 12 \times 20$ & $600 \times 300 \times 12 \times 20$ \\
$5-7$ & KC & WF & WF \\
& $700 \times 300 \times 13 \times 24$ & $500 \times 200 \times 10 \times 16$ & $500 \times 200 \times 10 \times 16$ \\
$8-10$ & KC & WF & WF \\
& $600 \times 300 \times 12 \times 20$ & $400 \times 200 \times 8 \times 13$ & $400 \times 200 \times 8 \times 13$ \\
\hline
\end{tabular}

Pada program SAP 2000, pemodelan frame dilakukan dengan cara penginputan material pada Define $>$ Material $>$ Add New Material $>$ Material Property Data. Kemudian setelah input material selesai tahapan selanjutnya yaitu define penampang yang digunakan pada Define $>$ Section Properties $>$ Frame Properties $>$ Add New Property, untuk penampang Wide Flange dan King Cross. Setelah itu dilakukan penggambaran 3D model bangunan gedung 10 lantai seperti pada Gambar 5 dengan ilustrasi SPSW yang memiliki opening persegi seperti pada Gambar 4.

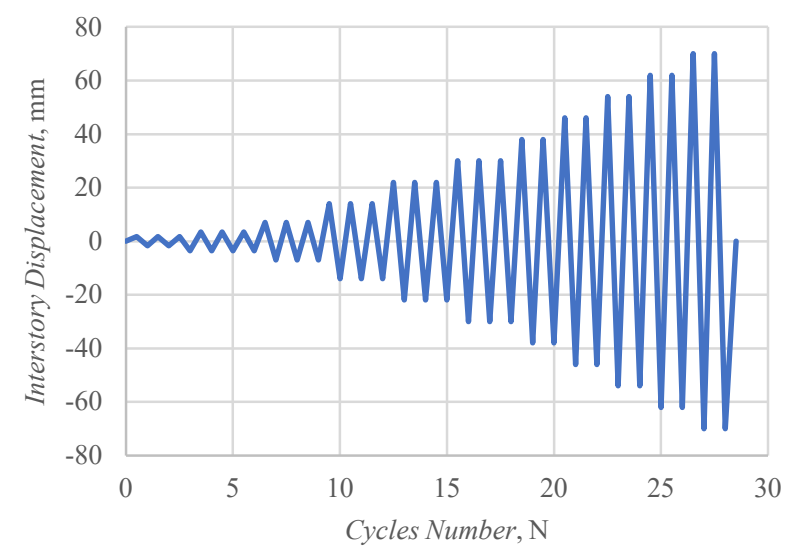

Gambar 3. Pembebanan Siklik pada Abaqus sesuai Protokol ATC-24 [6]

Pembebanan pada gedung 10 lantai diimplementasikan pada setiap lantai meliputi beban hidup, beban mati tambahan dan beban gempa yang berupa respons spektrum[11]. Pembebanan lantai yang digunakan mengikuti Tabel 2.

Pada gedung ini diasumsikan digunakan sebagai apartemen yang berada pada Surabaya, sehingga untuk wilayah gempa menggunakan Surabaya. Pada SNI 1726:2019 Tabel 3 [12] untuk kategori resiko gedung hunian yaitu II, dengan nilai $I_{e}=1,0$. Parameter gempa diambil dengan menggunakan program bantu Peta Gempa dan Respons Spektra 2019 
(PUSGEN-PUSKIM PUPR, 2019-2020), sehingga didapatkan grafik respon spektrum seperti pada Gambar 6.

Tabel 2. Beban Mati Tambahan dan Beban Hidup

\begin{tabular}{clcc}
\hline No & \multicolumn{1}{c}{ Beban } & $\mathrm{Kg} / \mathrm{m}^{2}$ & Lantai \\
\hline 1 & $\begin{array}{l}\text { Beban mati tambahan pelat } \\
\text { lantai }\end{array}$ & 135,5 & $2-9$ \\
2 & Beban mati tambahan pelat atap & 35,5 & 10 \\
3 & Beban hidup pelat lantai & 192 & $2-9$ \\
4 & Beban hidup pelat atap & 97 & 10 \\
\hline
\end{tabular}

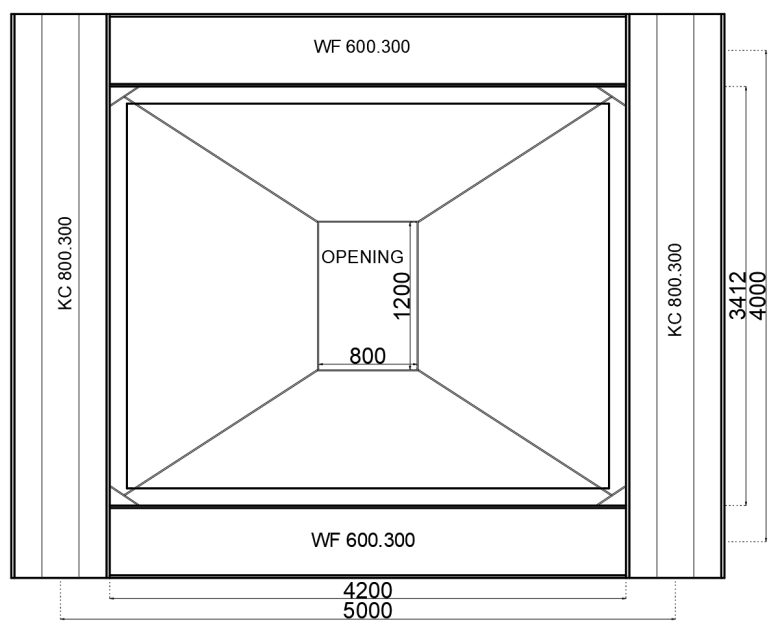

Gambar 4. Ilustrasi Pemodelan SPSW pada SAP 2000
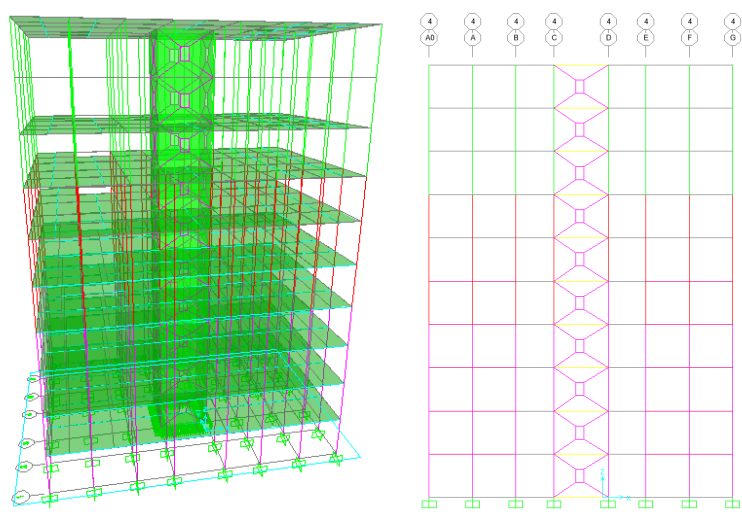

Gambar 5. Pemodelan Gedung 10 Lantai menggunakan SAP 2000

Kontrol pemodelan SAP 2000 dilakukan untuk pengecekan model bangunan sesuai dengan batasan yang diisyaratkan SNI 1726:2019 [12] terkait beban gempa yang diterapkan. Pengecekan model bangunan meliputi kontrol partisipasi massa, kontrol waktu getar alami fundamental, kontrol gaya dasar dinamis struktur, kontrol simpangan dan kontrol penampang.

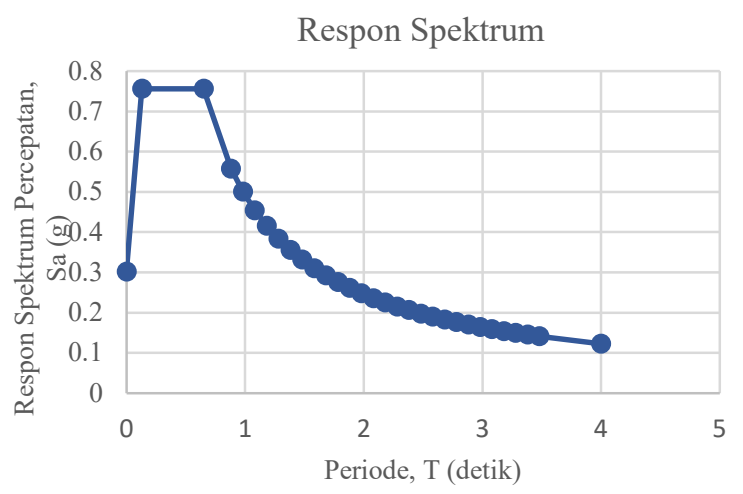

Gambar 6. Respon Spektrum

Kontrol terhadap partisipasi massa pada pemodelan struktur untuk perhitungan respon dinamik struktur harus sekurang-kurangnya 90\% untuk arah x maupun arah y struktur, sesuai dengan SNI 1726:2019 pasal 7.9.1.1[12]. Kontrol waktu getar alami fundamental struktur untuk mencegah bangunan mengalami getar terlalu besar. Berdasarkan SNI 1726:2019 didapatkan batasan perioda minimum seperti pada persamaan 1 dan batasan perioda maksimum seperti pada persamaan 2 .

$T_{a}=C_{t} \times h_{n}^{x}$

dimana:

$T_{a} \quad=$ Perioda fundamental struktur, $\mathrm{s}$

$h_{n} \quad=$ Ketinggian total struktur, $\mathrm{m}$

$C_{t} \quad=$ Parameter pendektan (SNI 1726:2019 Tabel 18)

$x \quad=$ Parameter pendektan (SNI 1726:2019 Tabel 18)

$T=T_{a} \times C_{u}$

dimana:

$C_{u} \quad=$ koefisien (SNI 1726:2019 Tabel 17)

Kontrol terhadap gaya geser dasar yang dialami struktur pada arah $\mathrm{x}$ dan y ditetapkan tidak boleh kurang dari 100\% dari nilai gaya geser statik yang didapatkan dari berat struktur, dimana nilai gaya geser $(V)$ dihitung melalui metode statik ekivalen seperti pada persamaan 3 .

$V=C_{S} \times W$

Dimana:

$V \quad=$ Gaya geser statis, $\mathrm{kg}$

$C_{S} \quad=$ Koefisien respons seismik

$W \quad=$ Berat seismik, $\mathrm{kg}$

Kontrol simpangan antar lantai didasarkan SNI 1726:2019 pasal 7.8.6, pembatasan simpangan antar lantai ini bertujuan untuk mencegah kerusakan non-struktural dan ketidaknyamanan penghuni. Dengan perhitungan nilai simpangan seperti pada persamaan 4 .

$\delta_{x}=\frac{C_{d} \times \delta_{x e 1}}{I e}$

Dimana: 
$\delta_{x} \quad=$ Simpangan lantai

$\delta_{x e 1}=$ Simpangan yang dihitung akibat beban gempa tingkat 1

$C_{d}=$ faktor pembesaran defleksi (SNI 1726:2019 Tabel 12)

Ie = faktor keutamaan gedung (SNI 1726:2019 Tabel 4)

Tahapan kontrol selanjutnya yaitu kontrol terhadap penampang. Kontrol penampang dilakukan dengan steel check design pada pemodelan Gedung mengacu AISC 36016 [2], steel check design bertujuan untuk mengetahui kapasitas penampang yang digunakan, dengan batasan rasio tidak boleh melebihi 1,00 .

\section{Hasil dan Pembahasan}

\section{A. Validasi Model SPSW(S4)}

Validasi pada spesimen SPSW(S4) yang dimodelkan pada program bantu Abaqus ditinjau dari hasil grafik histerisis, gaya geser maksimal, serta deformasi yang dihasilkan. Parameter tersebut digunakan sebagai pembanding analisis hasil dari eksperimental Alavi.

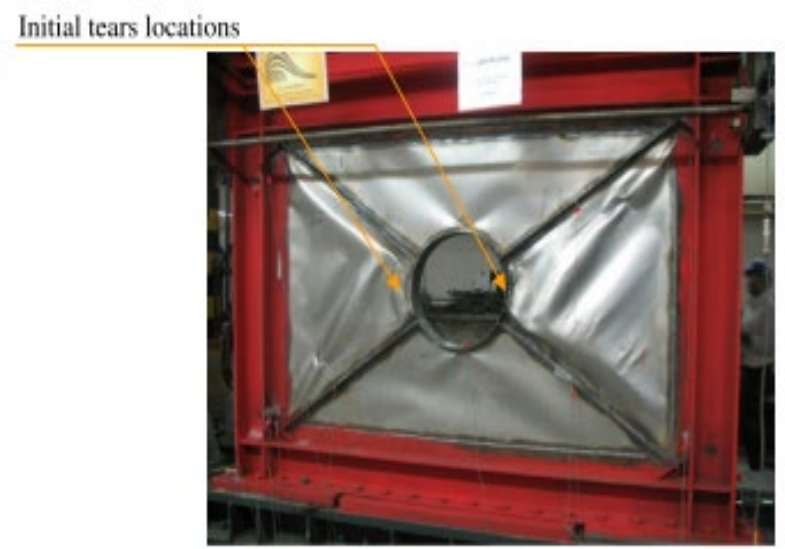

Tabel 3. Hasil perbandingan Drift Rasio dan Nilai Gaya Geser

\begin{tabular}{ccc}
\hline & $\begin{array}{c}\text { Eksperimental } \\
\text { Alavi }\end{array}$ & $\begin{array}{c}\text { Pemodelan } \\
\text { Abaqus }\end{array}$ \\
\hline $\begin{array}{c}\text { Drift saat pelelehan } \\
\text { pertama }\end{array}$ & $0.59 \%$ & $0.16 \%$ \\
$\begin{array}{c}\text { Drift saat gaya geser } \\
\text { Maksimal } \\
\text { Nilai gaya geser } \\
\text { maksimal }\end{array}$ & $3.80 \%$ & $4.11 \%$ \\
\hline
\end{tabular}

Pada Tabel 3, hasil eksperimental Alavi SPSW(s4) memiliki pelelehan awal yang terjadi pada displacement $8,9 \mathrm{~mm}$ $(0,59 \%)$, sedangkan pada pemodelan Abaqus pelelehan awal terjadi pada displacement $2,5 \mathrm{~mm}(0,16 \%)$. Kondisi pelelehan terjadi pada pelat pengisi yang tegangannya mencai
307-346 MPa di beberapa titik dan pada pelat pengaku lingkaran 423-461 MPa, seperti pada Gambar 8.

Pada drift 2,4\% SPSW (s4) eksperimental Alavi terjadi local tears pada pelat pengisi yang berada dekat dengan pelat pengaku lingkaran, seperti pada Gambar 7. Meskipun terjadi local tears, spesimen masih dapat menyerap energi hingga $740 \mathrm{kN}$ pada drift 3,8\%, kemudian spesimen mengalami degrasi dan berhenti pada siklus pembebanan ke-28.

Sedangkan pemodelan spesimen SPSW(s4) menggunakan Abaqus, pada drift 2,66\%, pada pelat pengaku lingkaran mengalamai tegangan paling besar (594-648 MPa) dan pada pelat pengisinya terjadi tegangan (432-486 $\mathrm{MPa})$, seperti pada Gambar 9. Gaya geser maksimum yang terjadi $710 \mathrm{kN}$ pada drift 4,11\%, seperti pada eksperimental, spesimen juga mengalamai degradasi energi yang diserap hingga siklus ke28. Kondisi akhir dari spesimen dapat dilihat pada Gambar 10 untuk pemodelan Abaqus, dan Gambar 11 hasil eksperimental Alavi.
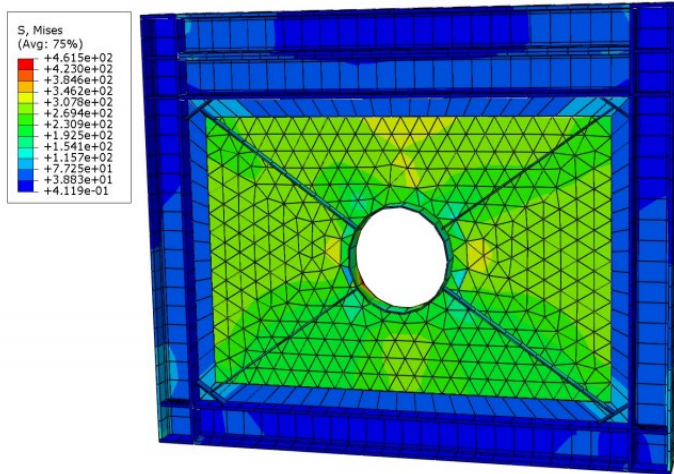

Gambar 8. Pelelehan pertama pada SPSW(s4) di Abaqus saat drift $0,16 \%$

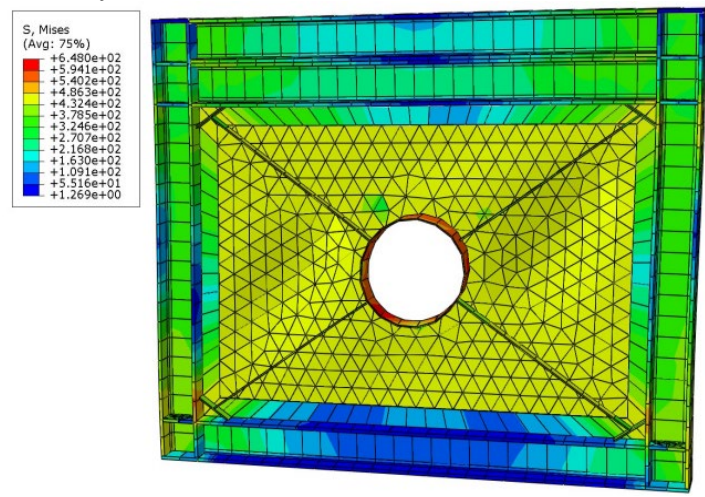

Gambar 9. Tegangan Von-Mises saat drift 2.66\%

Gambar 12 dan Gambar 13 menunjukkan kurva histerisis spesimen SPSW(s4) pada eksperimen oleh Alavi dan pemodelan abaqus, dengan nilai gaya geser maksimal pada eksperimen oleh Alavi $740 \mathrm{kN}$ pada drift 3,8\% [6] dan pada pemodelan menggunakan Abaqus $710 \mathrm{kN}$ pada drift 4,11\%. Selisih dari hasil perbandingan gaya geser adalah $4,05 \%$ dari 
eksperimental. Pada Gambar 14 merupakan gabungan dari kurva histeresis eksperimental Alavi dan pemodelan Abaqus.

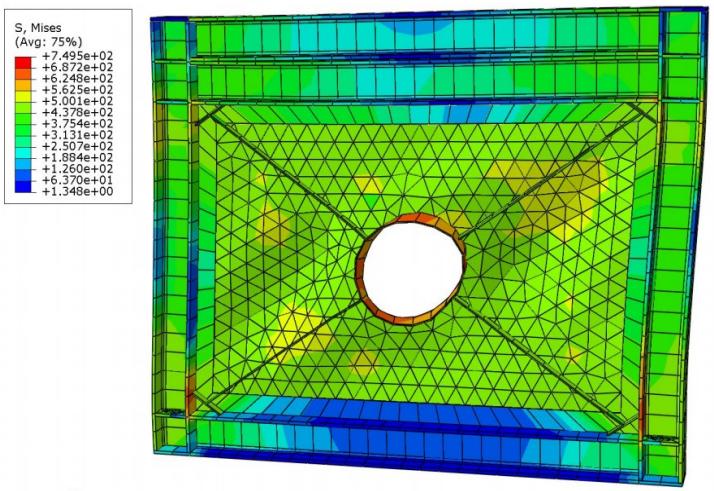

Gambar 10. Tegangan Von-Mises saat drift 4,.62\%

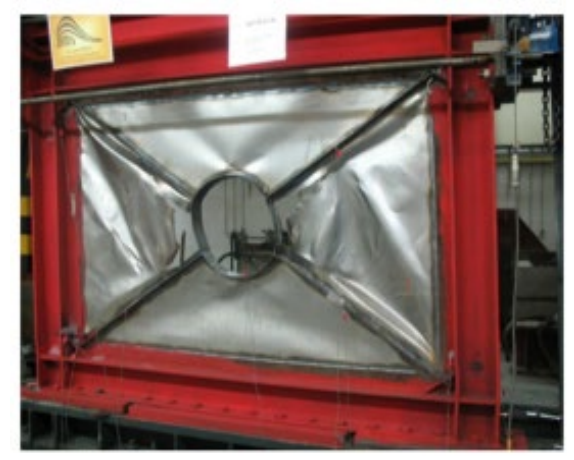

Gambar 11. Tegangan saat drift 4,4\% eksperimental Alavi [6]

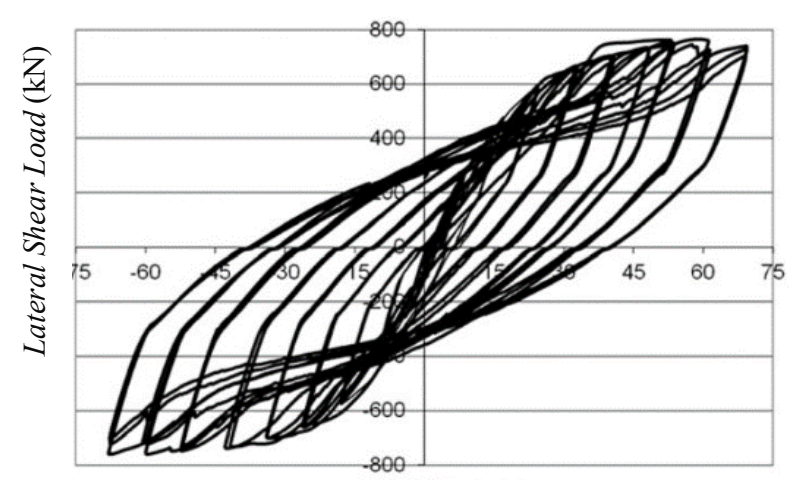

Displacement (mm)

Gambar 12. Kurva Histeresis SPSW (s4) eksperimental Alavi [6]

\section{B. Pemodelan SPSW dengan Opening pada Gedung 10 Lantai \\ Pada pemodelan gedung 10 lantai dengan adanya SPSW} dengan opening pada core bangunan menggunakan program bantu SAP 2000, dilakukan beberapa kontrol pada pemodelan meliputi kontrol partisipasi massa, kontrol periode fundamental struktur, kontrol gaya dasar dinamis struktur, kontrol simpangan antar lantai dan analisis kontrol penampang. Berikut rincian pembahasan terkait kontrol terhadap model:

1) Kontrol Partipasi Massa

Menurut SNI 1726:2019 pasal 7.9.1.1 hasil analisis didapatkan partisipasi masa ragam terkombinasi paling sedikit $90 \%$ dari massa aktual dalam masing-masing arah. Dari hasil analisis menggunakan program bantu SAP 2000, didapatkan partisipasi massa arah X: 94,12\% dan partisipasi massa arah Y: 94,11 \% seperti pada Tabel 4, maka dapat disimpulkan analisis struktur telah memenuhi syarat partisipasi massa ragam paling sedikit $90 \%$.

Tabel 4. Partisipasi massa

\begin{tabular}{ccccc}
\hline \multicolumn{5}{c}{ Participation Ratios } \\
\hline OutputCase & ItemType & Item & Static & Dynamic \\
Text & Text & Text & Percent & Percent \\
\hline MODAL & Acceleration & UX & 99,9189 & 94,1243 \\
MODAL & Acceleration & UY & 99,9351 & 94,1088 \\
MODAL & Acceleration & UZ & 0,0059 & 0,0004445 \\
\hline
\end{tabular}

2) Kontrol Periode Fundamental Struktur

Untuk mendapatkan struktur bangunan yang kaku, nilai waktu getar alami $(T)$ dari struktur harus dibatasi sesuai SNI1726:2019. Berdasarkan SNI 1726:2019 persamaan 26 didapatkan perioda minimum $\left(T_{a}=C_{t} \times h_{n}^{x}\right)$, dengan nilai parameter periode pendekatan $C_{t}=0,0488$ dan x $=0,75$ pada Tabel 18 SNI 1726:2019.

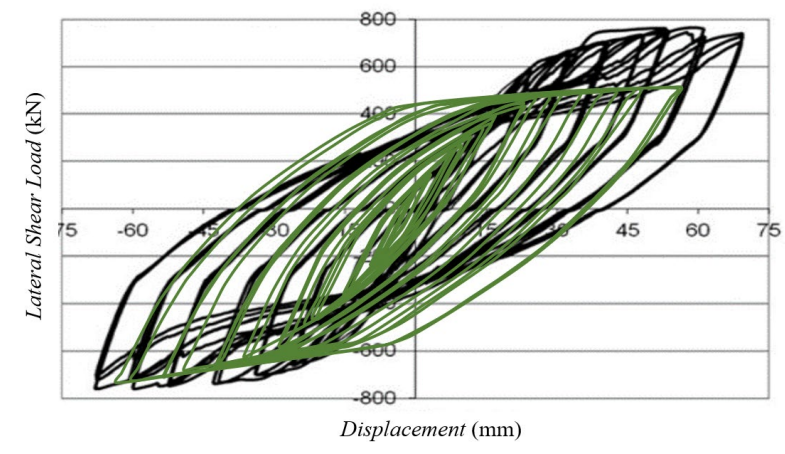

Gambar 13. Gabungan Kurva Histeresis Eksperimental Alavi dan pemodelan Abaqus

$T_{a}=C_{t} \times h_{n}^{x}=0,7762 \mathrm{~s}$

Untuk periode maksimum nilai peroda tersebut dikali faktor $C_{u}$. Periode maksimal menentukan batas atas periode yang dihitung, harus ditinjau parameter percepatan respons spectral design pada 1 detik $\left(\mathrm{S}_{\mathrm{D} 1}>0,4\right)$ sehingga untuk $C_{u}$ diambil 1,4. 
$T=T_{a} \times C_{u}=1,0867 \mathrm{~s}$

Pada analisis menggunakan program bantu SAP 2000, periode yang didapatkan pada modal 1 yaitu $1,0846 \mathrm{~s}$ tertera pada Gambar 15, sehingga periode tersebut kurang dari periode maksimum dan masih memenuhi ketentuan.

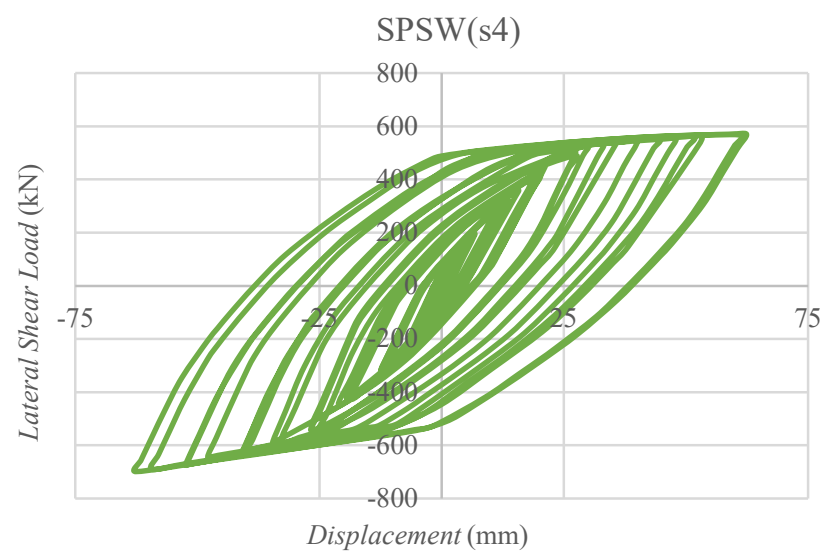

Gambar 14. Kurva Histeresis Validasi Spesimen SPSW(s4) dengan Abaqus

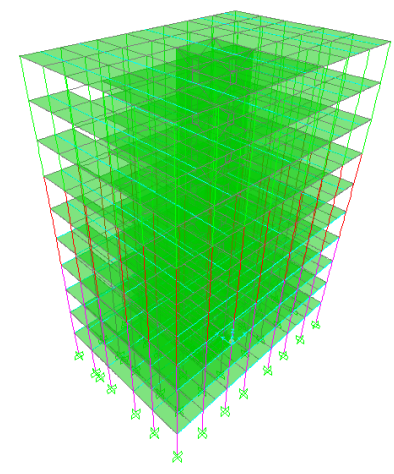

Gambar 15. Perioda (T) pada Modal 1

3) Kontrol Gaya Dasar Dinamis Struktur

SNI 1726:2019 Pasal 7.9.1.4.1 menjelaskan apabila kombinasi respons untuk gaya geser dasar hasil analisis ragam $\left(V_{t}\right)$ kurang dari $100 \%$ dari gaya geser $(V)$ yang dihitung melalui metode statik ekivalen, maka gaya tersebut harus dikalika $V / V_{t}$. Pada Tabel 12 SNI 1726:2019 untuk koefisien modifikasi respon $(R)$ dinding geser pelat baja khusus yaitu 8 dan faktor pembesaran defleksi $\left(C_{d}\right)$ yaitu 6,5 . Koefisien respons seismik didapat sebagai berikut:

$C_{S}=\frac{S_{D S}}{R / I e}=0,0945$

Nilai $C_{S}$ tidak boleh lebih dari:

$C_{s}=\frac{S_{D 1}}{T \times(R / I e)}=0,0566$

Nilai $C_{S}$ tidak kurang dari:
$C_{s}=0,044 \times S_{D S} \times I e=0,0333$

Sehingga nilai $C_{s}$ diambil 0,0566

Dari hasil analisis SAP 2000, diperoleh berat total struktur seperti pada Tabel 5 dengan total berat struktur $W=$ $7.651 .694,81 \mathrm{~kg}$.

Tabel 5. Berat Struktur

\begin{tabular}{ccc}
\hline OutputCase & CaseType & $\begin{array}{c}\text { GlobalFZ } \\
\text { Kgf }\end{array}$ \\
\hline DEAD & LinStatic & $6.047 .742,31$ \\
LIVE & LinStatic & 951.152 \\
BEBAN & LinStatic & $652.800,5$ \\
TAMBAHAN & & $7.651 .694,81$ \\
W & &
\end{tabular}

Sehingga untuk gaya geser statik, sebagai berikut: $V_{\text {statik }}=C_{s} \times W=433239,45 \mathrm{~kg}$

Dari hasil analisis dinamis gaya geser pada SAP 2000, diperoleh gaya geser akibat gempa $\mathrm{x}$ dan y seperti pada Tabel 6.

Tabel 6. Gaya Geser akibat Gempa x dan y

\begin{tabular}{ccc}
\hline OutputCase & $\begin{array}{c}\text { GlobalFX } \\
\text { kgf }\end{array}$ & $\begin{array}{c}\text { GlobalFY } \\
\text { kgf }\end{array}$ \\
\hline Ex & 407837,6 & 2207,52 \\
Ey & 2207,56 & 365638,94 \\
\hline
\end{tabular}

Kontrol gaya geser:

Gempa arah $\mathrm{x}$

$V_{\text {dinamik }} \geq 100 \% V_{\text {statik }}$

$407837,6 \leq 433239,45$ (Not OK)

Gempa arah y

$V_{\text {dinamik }} \geq 100 \% V_{\text {statik }}$

$365638,94 \leq 433239,45$ (Not OK)

Dari kontrol di atas, bangunan belum memenuhi syarat nilai akhir respons. Pada Pasal 7.9.4.2 SNI 1726:2019 dijelaskan apabila gaya geser dasar hasil analisis kurang dari $100 \%$, maka harus diperbesar dengan faktor skala $\frac{C_{S} \times W}{V}$

$\frac{C_{S} \times W}{V}=\frac{0,0566 \times 7651694,81}{407837,6}=1,06228$

Arah y

$\frac{C_{s} \times W}{V}=\frac{0,0566 \times 7651694,81}{365638,94}=1,18488$

Setelah dikalikan skala, didapatkan gaya geser seperti pada

Tabel 7.

Kontrol gaya geser:

Gempa arah $\mathrm{x}$

$V_{\text {dinamik }} \geq 100 \% V_{\text {statik }}$

$462770,82 \geq 433239,45$ (OK)

Gempa arah y

$V_{\text {dinamik }} \geq 100 \% V_{\text {statik }}$ 
$462645,19 \geq 433239,45$ (OK)

Dari kontrol diatas dapat disimpulkan bahwa analisis struktur gedung di atas masih memenuhi persyaratan SNI 1726:2019 Pasal 7.8.

Tabel 7. Gaya Geser setelah Pembesaran

\begin{tabular}{ccc}
\hline OutputCase & $\begin{array}{c}\text { GlobalFX } \\
\text { kgf }\end{array}$ & $\begin{array}{c}\text { GlobalFY } \\
\text { kgf }\end{array}$ \\
\hline Ex & 462770,82 & 2504,86 \\
Ey & 2793,24 & 462645,19 \\
\hline
\end{tabular}

4) Kontrol Simpangan Antar Lantai

Pembatasan simpangan antar lantai suatu struktur bertujuan untuk mencegah kerusakan non-struktur dan ketidaknyamanan penghuni. Simpangan yang terjadi dari hasil dinamis harus lebih kecil dari simpangan hasil analisis. Simpangan ijin $\Delta_{i}$ untuk tingkat 1 :

$\delta_{x}=\frac{C_{d} \times \delta_{x e 1}}{I e}$

Simpangan ijin $\Delta_{i}$ untuk tingkat 2 :

$\delta_{x}=\left(\delta_{x e 2}-\delta_{x e 1}\right) \frac{C_{d}}{I e}$

Batasan ijin simpangan lantai diatur pada Tabel 16 SNI 1726:2019, dengan semua struktur lainnya $0,02 h_{a x}$, dengan tinggi antar lantai $4 \mathrm{~m}$. Sehingga pada analisis menggunakan program bantu SAP 2000 didapatkan simpangan antar lantai untuk gempa arah x dan y seperti pada Tabel 8 dan Tabel 9.

Pada Gambar 16 dan Gambar 17 merupakan hasil perpindahan lateral yang dialami Gedung SPSW, dengan perpindahan arah Y lebih besar dibandingkan dengan arah X. Sedangkan Gambar 18 dan Gambar 19 menunjukkan simpangan antar lantai, pada arah Y simpangan terbesar berada pada lantai 5 , sedangkan arah X simpangan terbesar berada pada lantai 7.

Tabel 8. Simpangan antar lantai gempa arah $\mathrm{Y}$

\begin{tabular}{ccccccc}
\hline Lantai & $\begin{array}{c}\text { Elevasi } \\
(\mathrm{m})\end{array}$ & $\begin{array}{c}\delta \mathrm{e} \\
(\mathrm{mm})\end{array}$ & $\begin{array}{c}\delta \mathrm{xe} \\
(\mathrm{mm})\end{array}$ & $\begin{array}{c}\delta \mathrm{x} \\
(\mathrm{mm})\end{array}$ & $\begin{array}{c}\Delta \mathrm{ijin} \\
(\mathrm{mm})\end{array}$ & Ket \\
\hline 10 & 40 & 35.17 & 1.92 & 12.48 & 80.00 & $\mathrm{OK}$ \\
9 & 36 & 33.25 & 2.72 & 17.68 & 80.00 & $\mathrm{OK}$ \\
8 & 32 & 30.53 & 3.43 & 22.30 & 80.00 & $\mathrm{OK}$ \\
7 & 28 & 27.10 & 3.68 & 23.92 & 80.00 & $\mathrm{OK}$ \\
6 & 24 & 23.42 & 4.07 & 26.46 & 80.00 & $\mathrm{OK}$ \\
5 & 20 & 19.35 & 4.40 & 28.60 & 80.00 & $\mathrm{OK}$ \\
4 & 16 & 14.95 & 4.26 & 27.69 & 80.00 & $\mathrm{OK}$ \\
3 & 12 & 10.69 & 4.28 & 27.82 & 80.00 & $\mathrm{OK}$ \\
2 & 8 & 6.41 & 3.96 & 25.74 & 80.00 & $\mathrm{OK}$ \\
1 & 4 & 2.45 & 2.45 & 15.93 & 80.00 & $\mathrm{OK}$ \\
0 & 0 & 0.00 & 0.00 & 0.00 & 80.00 & $\mathrm{OK}$ \\
\hline
\end{tabular}

Tabel 9. Simpangan antar Lantai Gempa arah X

\begin{tabular}{ccccccc}
\hline Lantai & $\begin{array}{c}\text { Elevasi } \\
(\mathbf{m})\end{array}$ & $\begin{array}{c}\boldsymbol{\delta e} \\
(\mathbf{m m})\end{array}$ & $\begin{array}{c}\boldsymbol{\delta x e} \\
(\mathbf{m m})\end{array}$ & $\begin{array}{c}\boldsymbol{\delta} \mathbf{m} \\
(\mathbf{m m})\end{array}$ & $\begin{array}{c}\boldsymbol{\Delta} \text { ijin } \\
(\mathbf{m m})\end{array}$ & Ket \\
\hline 10 & 40 & 27.54 & 1.71 & 11.12 & 80.00 & OK \\
9 & 36 & 25.83 & 2.49 & 16.19 & 80.00 & OK \\
8 & 32 & 23.34 & 3.12 & 20.28 & 80.00 & OK \\
7 & 28 & 20.22 & 3.30 & 21.45 & 80.00 & OK \\
6 & 24 & 16.92 & 3.24 & 21.06 & 80.00 & OK \\
5 & 20 & 13.68 & 3.07 & 19.96 & 80.00 & OK \\
4 & 16 & 10.61 & 2.93 & 19.05 & 80.00 & OK \\
3 & 12 & 7.68 & 2.95 & 19.18 & 80.00 & OK \\
2 & 8 & 4.73 & 2.81 & 18.27 & 80.00 & OK \\
1 & 4 & 1.92 & 1.92 & 12.48 & 80.00 & OK \\
0 & 0 & 0.00 & 0.00 & 0.00 & 80.00 & OK \\
\hline
\end{tabular}

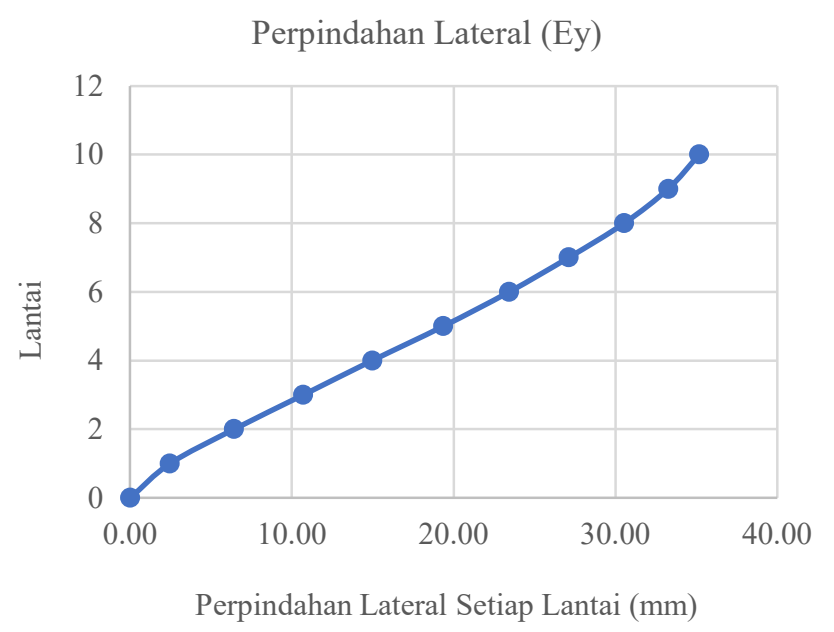

Gambar 16. Perpindahan Lateral Arah Y

Perpindahan Lateral (Ex)

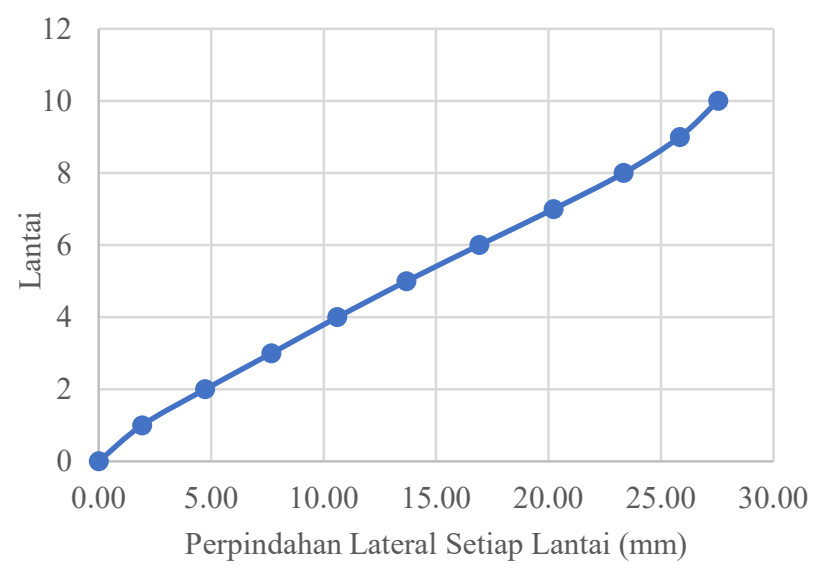

Gambar 17. Perpindahan lateral arah $X$ 


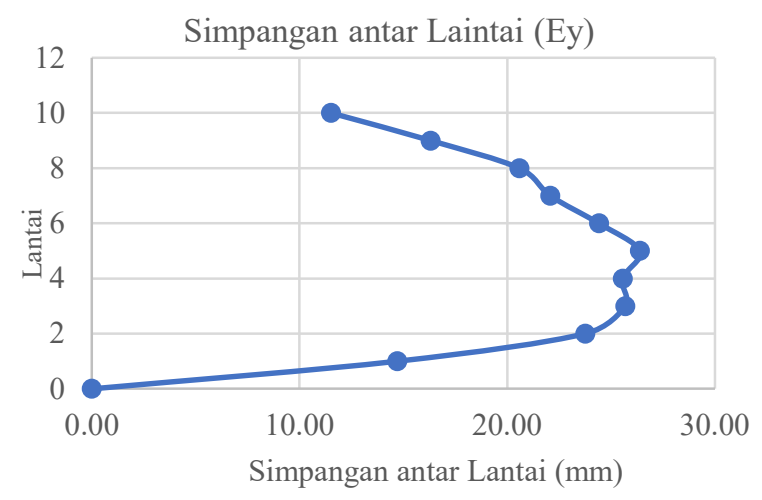

Gambar 18. Simpangan antar Lantai arah Y

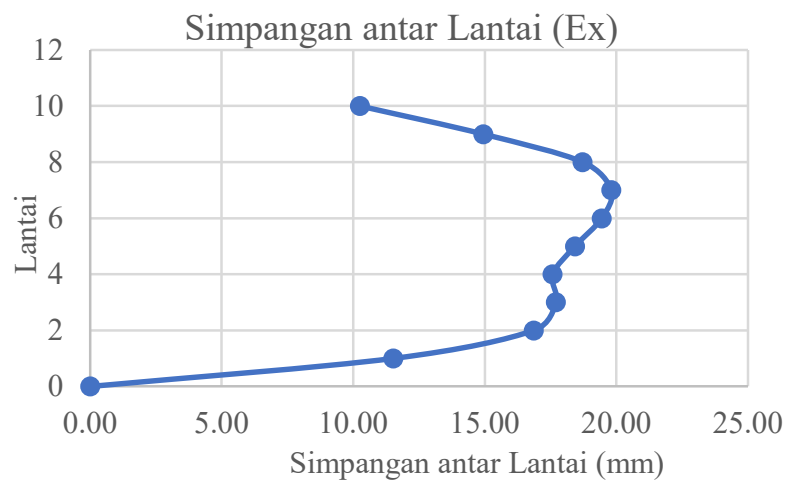

Gambar 19. Simpangan antar lantai arah $X$

5) Analisis Kontrol Penampang

Pada analisis menggunakan program bantu SAP 2000 kontrol kekuatan penampang diperlukan untuk mengetahui dan memastikan penampang yang digunakan telah sesuai dengan persyaratan. Persyaratan yang digunakan pada SAP 2000 yiatu AISC 360-16.

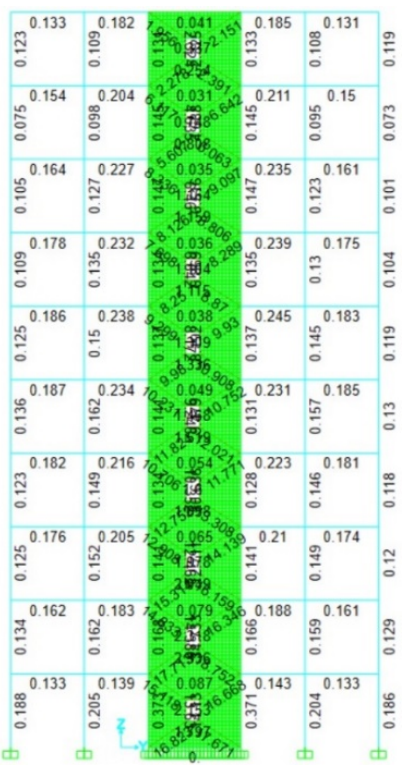

Gambar 20. Steel Check Design arah y
Dari hasil steel check desain seperti pada Gambar 20 dan Gambar 21 yang menggunakan persyaratan AISC 360-16 untuk elemen balok dan kolom memiliki rasio yang tidak melebihi 0,5, sehingga aman digunakan sebagai profil bangunan.

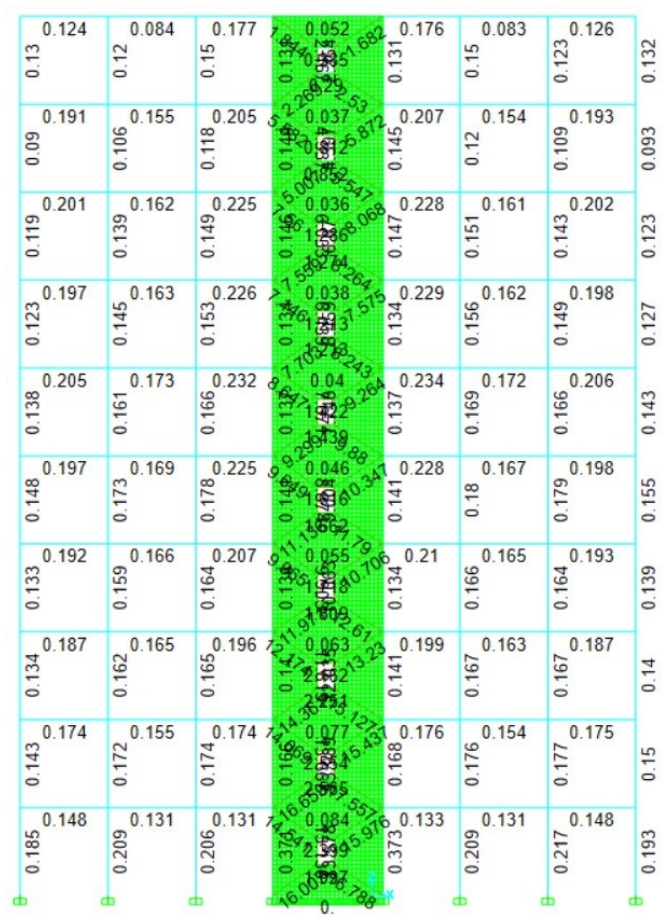

Gambar 21. Steel Check Design arah x

\section{Simpulan}

Berdasarkan penelitian yang telah dilakukan, dapat disimpulkan sebagai berikut:

1) Pada pemodelan Steel Plate Shear Wall (SPSW) menggunakan program bantu Abaqus, didapatkan hasil validasi spesimen SPSW(S4) yaitu nilai gaya geser maksimal yang tercapai tidak jauh berbeda, pada eksperimental 740 $\mathrm{kN}$ saat drift 3,80\% dan pada pemodelan menggunakan Abaqus $710 \mathrm{kN}$ saat drift 4,11\%, sehingga selisih dari hasil perbandingan gaya geser adalah $4,05 \%$ dari eksperimental.

2) Pola kegagalan pada spesimen SPSW(S4) terjadi pada pelat pengisi, hal ini ditandai dengan adanya bidang tarik diagonal pada eksperimental Alavi. Pada pemodelan Abaqus pelelehan pertama terjadi pada pelat pengisi ditandai dengan tercapainya tegangan pelat pengisi 307 MPa.

3) Pada pengaplikasian SPSW dengan opening pada Gedung 10 lantai di dapatkan profil untuk HBE yaitu WF 600x300 dan VBE yaitu KC 800x300, dengan menggunakan pelat pengisi ketebalan $4 \mathrm{~mm}$ dan pelat pengaku $12 \mathrm{~mm}$. 
4) Pada model Gedung 10 lantai dengan SPSW yang terdapat opening, kontrol desain struktur terkait kontrol partisipasi massa, kontrol periode getar struktur, kontrol gaya geser dinamis struktur, kontrol simpangan, dan kontrol penampang telah memenuhi persyaratan.

\section{Daftar Pustaka}

[1] R. S.. Bruneau, Michel Ph.D.,P.Eng; Uang, ChiaMing Ph.D.; Sabelli, Ductile Design of Steel Structures. United States of Amarica: The McGrawHill Companies, 2011.

[2] AISC, "Seismic Provisions for Structural Steel Buildings, ANSI/AISC 341-10," Struct. Anal. Des. Tall Build., pp. 355-410, 2011, doi: 10.1201/b112488.

[3] M. Wang, W. Yang, Y. Shi, and J. Xu, "Seismic behaviors of steel plate shear wall structures with construction details and materials," J. Constr. Steel Res., vol. 107, pp. 194-210, 2015, doi: 10.1016/j.jcsr. 2015.01.007.

[4] A. Schumacher and G. Y. Grondin, "Connection of Infill Panels in Steel Plate Shear Wall," no. 217, 1997.

[5] C. Dou, Z. Q. Jiang, Y. L. Pi, and Y. L. Guo, "Elastic shear buckling of sinusoidally corrugated steel plate shear wall," Eng. Struct., vol. 121, pp. 136-146, 2016, doi: 10.1016/j.engstruct.2016.04.047.
[6] E. Alavi and F. Nateghi, "Experimental study on diagonally stiffened steel plate shear walls with central perforation," J. Constr. Steel Res., vol. 89, pp. 9-20, 2013, doi: 10.1016/j.jcsr.2013.06.005.

[7] S. Sabouri-Ghomi and S. Mamazizi, "Experimental investigation on stiffened steel plate shear walls with two rectangular openings," Thin-Walled Struct., vol. 86, pp. 56-66, 2015, doi: 10.1016/j.tws.2014.10.005.

[8] O. Haddad, N. H. Ramli Sulong, and Z. Ibrahim, "Cyclic performance of stiffened steel plate shear walls with various configurations of stiffeners," $J$. Vibroengineering, vol. 20, no. 1, pp. 459-476, 2018, doi: $10.21595 /$ jve.2017.18472.

[9] D. L. Logan, A First Course In The Finite Element Method. 2012.

[10] A. Khennane, Introduction to FEA using Matlab and ABAQUS. 2013.

[11] Badan Standarisasi Nasional, "Spesifikasi untuk bangunan gedung baja struktural Badan Standardisasi Nasional (SNI 1729:2015)," Bandung, pp. 1-289, 2015, [Online]. Available: www.bsn.go.id.

[12] Badan Standardisasi Nasional, "Tata cara perencanaan ketahanan gempa untuk struktur bangunan gedung dan nongedung," Tata Cara Perenc. Ketahanan Gempa Untuk Strukt. Bangunan Gedung dan Non Gedung, no. 8, p. 254, 2019. 